\title{
Prevalence of Hypercholesterolemia among Nurses in Hospitals of Thiruvananthapuram, Kerala
}

\author{
D. K. Meera ${ }^{1}$ and Suma Divakar ${ }^{2}$ \\ ${ }^{1}$ Research Scholar, ${ }^{2}$ Associate Professor, \\ Kerala University Library, Research centre, University of Kerala, Palayam, Thiruvananthapuram, Kerala, India \\ E-Mail: meerasunil@gmail.com
}

\begin{abstract}
The main objective is to study the prevalence of hypercholesterolemia among nurses working on shift and ascertain its association with socio economic parameters. The study was a cross sectional comparative study using randomized sampling technique. The sample population consisted of registered nurses working in randomly selected government and private hospitals in rural and urban areas of Thiruvananthapuram city. A Uniform sample size of 250 each were drawn from government and private hospitals of Thiruvananthapuram district to form a population size $(\mathrm{N}=500)$. Again a sub sample size of 25 each were drawn from government and private hospitals in rural and urban areas of Thiruvananthapuram $(\mathrm{N}=100)$ for the in depth studies. Only female nurses were included in the study who had minimum of five year experience and those who belonged to the age group between 25-45yrs. All the respondents selected for the study were doing their work on shift base from the day of joining their duty, which is the other condition for the study. A pretested schedule was used to elicit information using interview method. The information regarding demographic characteristics, shift details, medication, morbidity details and physical activities were collected. To estimate the level of total cholesterol, blood samples were collected from the subsample of 100 subjects from each group. Chi square tests were carried out for analysing the quantitative and categorized variables. Out of fifty respondents from private hospitals, the prevalence of border line hypercholesterolemia was thirty two percent and the prevalence of high risk hypercholesterolemia was ten percent. Results from respondents of government hospital also gave the same. Total cholesterol assessed in the subject from the two sectors was not significantly associated with age $\left(\chi^{2}=8.738 ; \chi^{2}=6.051\right)$, experience $\left(\chi^{2}=1.002 ; \chi^{2}=1.181\right)$ and area of residence $\left(\chi^{2}=8.793 ; \chi^{2}=2.062\right)$. The blood sample analysis revealed that a significant number of respondents were considered to be border line risk and high risk of hypercholesterolemia which suggests that irregular shift hours can be associated with increased risk of hypercholesterolemia leads to further fatal condition. However level of total cholesterol was not significantly influenced by factors like age, work experience and area of residence.
\end{abstract}

Keywords: Female Nurses, Hypercholesterolemia, Private and Government Hospital, Rural, Urban, India

\section{INTRODUCTION}

Within the health sector when we take the nursing profession, they focused on the care of individuals, families and community at large, with the area of maintaining or recovering optimal health and quality of life. On comparing the nurses with other health care providers, by their approach to patient care, training and scope of practice are all found to be different. All such traditional role come to shape the historic public image of nurse as care providers (Velhal G.D. et al., 2013).

Nurses are group of employees who often work on shift hours in hospitals. As a part of their profession they mostly involved in multiple tasks, anxiety and stress along with various job related hazards. According to WHO cardiovascular diseases are the number one cause of death globally (WHO, 2015), so it is important to identify the risks as early as possible in light of the public health in many societies.

Hypercholesterolemia is a major risk factor for coronary atherosclerosis which later leads to heart attack. Other important contributors of hypercholesterolemia include diabetes, renal disease and cerebral vascular disease (Chen and Tseng, 2013).

As these workers work for irregular hours, their daily routine is interrupted which leads to serious health problems. The study ascertained the level of blood cholesterol of these health workers working on shift and analysed the same with their socio economic back ground.

\section{MATERIALS AND METHODS}

\section{A. Study Design and Sample}

The study was designed as a cross sectional comparative study using randomized sampling technique. The sample population consisted of registered nurses working in randomly selected government and private hospitals in rural and urban areas of Thiruvananthapuram city. Uniform sample size of 250 each were drawn from government and private hospitals of Thiruvananthapuram district to form a population size $(\mathrm{N}=500)$. A sub sample of 25 respondents were drawn from government and private hospitals in rural and urban areas of Thiruvananthapuram $(\mathrm{N}=100)$, for in depth studies. Only female nurses were included in the study who had a minimum of five year experience and those belonged to the age group between 25-45yr. All the respondents selected for the study were doing their work on shift bases from the day of joining their duty, which was also a criteria for selection. 
A pretested schedule was used to elicit information using interview method. The information regarding demographic characteristics, shift details, morbidity details and daily work pattern were collected. With the prior permission of the hospital administration, the investigator directly contacted the participants after fixing a convenient time with the respondents with the sanction of the Nursing Superintendents of the concerned hospitals. The place and the time was fixed by the respondents themselves. If the participants were comfortable at their work place, interview was conducted at their work place itself, without disturbing the routine work schedule, preferably after the working hours. Ethical clearance from the Ethics committee was obtained. Written informed consent was obtained from the respondents prior to the start of the interview.

\section{B. Assessment of Cholesterol Levels}

Cholesterol is an important material for the body metabolism. It has many other role in our body such as the synthesis of vitamin D, steroid hormones and bile acids. At the same time there are so many evidences which show that cholesterol is an important risk factor in the development of atherosclerosis (Menon et al., 2015). According NCEP (2013) the normal level of total cholesterol is $<200 \mathrm{mg} / \mathrm{dl}$, $200-239 \mathrm{mg} / \mathrm{dl}$ is considered as boarder line high and $\geq 240$ $\mathrm{mg} / \mathrm{dl}$ is considered as high level cholesterol. Cholesterol measures are considered markers of the risk of the heart disease. It is important to mention that there are so many studies that have reported both positive and negative relationship among shift work, occupational stress and cholesterol levels (Dochi et al., 2009; Uetani et al., 2011) For analyses of cholesterol level, blood samples were collected from the sub sample of 100 subjects. Blood samples were drawn from the subjects in the respective hospital labs, where they were working.

\section{Statistical Analysis}

Chi square test was carried out for analysing the quantitative categorized variables, $p$-value <.01, indicated significant relation at $1 \%$ level of significance and $p$-value<.05 indicated significant relation at $5 \%$ level of significance; similarly at $p$-value $>05$, there was no significant relation.

\section{RESULTS AND DISCUSSION}

As revealed in the table I, majority of the respondents of government hospitals (34.8\%) belonged to the age group 40-45 years while in private sector, majority of the respondents $(50 \%)$ belonged to the age group 30-35 years. Majority of the respondents in government hospital $(82.3 \%)$ and private hospitals $(87.6 \%)$ were married. Thirty three percentage of respondents in government hospitals which was considered as the majority belongs to 5 years of work experience while in private hospitals, majority of the respondents $(62.4 \%)$ were belonged to 5 to 10 years of experience. Majority of the respondents of government hospitals $(32.8 \%)$ belonged to the salary package between Rs30001-40000/- while in private sector , majority of the respondents $(78.8 \%)$ belonged to the salary between Rs 20001-30000/-.

TABle I Demographic Profile Of The ResPondents

\begin{tabular}{|c|c|c|c|c|c|}
\hline \multirow{2}{*}{ Particulars } & \multirow{2}{*}{ Category } & \multicolumn{2}{|c|}{$\begin{array}{c}\text { Government Hospital } \\
N=250\end{array}$} & \multicolumn{2}{|c|}{$\begin{array}{c}\text { Private Hospital } \\
\mathrm{N}=\mathbf{2 5 0}\end{array}$} \\
\hline & & $\begin{array}{c}\text { Rural } \\
\mathrm{N}=\mathbf{1 2 5}(\%)\end{array}$ & $\begin{array}{c}\text { Urban } \\
\mathbf{N}=\mathbf{1 2 5}(\%)\end{array}$ & $\begin{array}{c}\text { Rural } \\
\mathrm{N}=125(\%)\end{array}$ & $\begin{array}{c}\text { Urban } \\
\mathrm{N}=125(\%)\end{array}$ \\
\hline Age (yrs) & $\begin{array}{l}25-30 \\
30-35 \\
35-40 \\
40-45\end{array}$ & $\begin{array}{c}26(10.4) \\
27(10.8) \\
20(8.0) \\
52(20.8)\end{array}$ & $\begin{array}{c}16(6.4) \\
58(23.2) \\
16(6.4) \\
35(14.0)\end{array}$ & $\begin{array}{c}38(15.2) \\
64(25.6) \\
17(6.8) \\
6(2.4)\end{array}$ & $\begin{array}{c}45(18.0) \\
61(24.4) \\
14(5.6) \\
5(2.0)\end{array}$ \\
\hline Marital status & $\begin{array}{c}\text { Married } \\
\text { Unmarried } \\
\text { Widowed } \\
\text { Divorced } \\
\text { Separated }\end{array}$ & $\begin{array}{c}114(45.6) \\
9(3.6) \\
1(0.4) \\
1(1) \\
0(0.0)\end{array}$ & $\begin{array}{c}94(37.6) \\
31(12.4) \\
0(0.0) \\
0(0.0) \\
0(0.0)\end{array}$ & $\begin{array}{c}115(46.0) \\
89(2) \\
0(0.0) \\
0(0.0) \\
2(0.8)\end{array}$ & $\begin{array}{c}104(41.6) \\
19(7.6) \\
1(0.4) \\
1(0.4) \\
0(0.0)\end{array}$ \\
\hline $\begin{array}{c}\text { Year of } \\
\text { experience } \\
\text { (yrs) }\end{array}$ & $\begin{array}{c}\text { Up to } 5 \text { years } \\
>5-10 \text { years } \\
>10-15 \text { years } \\
>15 \text { years }\end{array}$ & $\begin{array}{c}36(14.4) \\
34(13.6) \\
18(7.2) \\
37(14.8)\end{array}$ & $\begin{array}{c}47(18.8) \\
47(18.8) \\
14(5.6) \\
17(6.8)\end{array}$ & $\begin{array}{c}19(7.6) \\
71(28.4) \\
26(10.4) \\
9(3.6)\end{array}$ & $\begin{array}{c}24(9.6) \\
85(34.0) \\
15(6.0) \\
1(0.4)\end{array}$ \\
\hline $\begin{array}{l}\text { Salary } \\
\text { (Rs) }\end{array}$ & $\begin{array}{c}5000-10000 \\
10001-15000 \\
15001-20000 \\
20001-30000 \\
30001-40000 \\
\text { Above } 40000\end{array}$ & $\begin{array}{c}3(1.2) \\
25(10.0) \\
3(1.2) \\
29(11.6) \\
30(11.6) \\
35(14.1)\end{array}$ & $\begin{array}{c}6(2.4) \\
8(3.2) \\
13(5.2) \\
19(7.6) \\
52(20.9) \\
27(10.8)\end{array}$ & $\begin{array}{c}3(1.2) \\
29(11.6) \\
93(37.2)\end{array}$ & $\begin{array}{c}4(1.6) \\
17(6.8) \\
104(41.6)\end{array}$ \\
\hline
\end{tabular}




\section{A. Association of Cholesterol and Age}

TABLE II AsSOCIATION Of TOTAL CHOLESTEROL With Age OF RESPONDENTS

\begin{tabular}{|c|c|c|c|c|c|c|}
\hline \multirow{2}{*}{\multicolumn{3}{|c|}{ Organization }} & \multicolumn{3}{|c|}{ Age } & \multirow{3}{*}{\begin{tabular}{|c|} 
Total \\
$29(58.0)$ \\
\end{tabular}} \\
\hline & & & \multirow{2}{*}{$\begin{array}{c}<\mathbf{3 0} \\
10(20.0)\end{array}$} & \multirow{2}{*}{$\begin{array}{l}30-39 \\
14(28.0)\end{array}$} & \multirow{2}{*}{$\begin{array}{l}>=40 \\
5(10)\end{array}$} & \\
\hline \multirow{4}{*}{$\begin{array}{c}* \text { Private } \\
\mathrm{N}=50\end{array}$} & \multirow{3}{*}{ Total Cholesterol } & Desirable & & & & \\
\hline & & Boarder line High & $2(4.0)$ & $8(16.0)$ & $6(12.0)$ & $16(32.0)$ \\
\hline & & High & $0(0.0)$ & $5(10.0)$ & $0(0.0)$ & $5(10.0)$ \\
\hline & \multicolumn{2}{|c|}{ Total } & $12(24.0)$ & $27(54.0)$ & $11(22.0)$ & $50(100.0)$ \\
\hline \multirow{4}{*}{$\begin{array}{l}* * \text { Govt } \\
\mathrm{N}=50 .\end{array}$} & \multirow{3}{*}{ Total Cholesterol } & Desirable & $6(12.0)$ & $11(22.0)$ & $12(24.0)$ & $29(58.0)$ \\
\hline & & Boarder line High & $0(0.0)$ & $5(10.0)$ & $11(22.0)$ & $16(32.0)$ \\
\hline & & High & $0(0.0)$ & $2(4.0)$ & $3(6.0)$ & $5(10.0)$ \\
\hline & \multicolumn{2}{|c|}{ Total } & $6(12.0)$ & $18(32.0)$ & $26(52.0)$ & $50(100.0)$ \\
\hline
\end{tabular}

Table II reveals that 42 percent of the respondents of private hospitals were having high cholesterol level (moderate and high) of whom 24 percent were having high levels of cholesterol. The age group more affected by high cholesterol level were 30-39 years.

In the case of government hospitals also 42 percent of respondents were seen to have high cholesterol levels, of which 52 percent were in the border level. The age group more affected here were above 40 years of age. However statistically the association of age and cholesterol levels were not found to be significant (*Chi square $8.738 \mathrm{p}$ value $=.068 ; * *$ Chi square $6.051 \mathrm{p}$-value $=.195)$.

\section{B. Association of Cholesterol and Experience}

TABLE III ASSOCIATION OF TOTAL CHOLESTEROL AND WORK EXPERIENCE

\begin{tabular}{|c|c|c|c|c|c|}
\hline & & & \multicolumn{2}{|c|}{ Experience } & \multirow{2}{*}{ Total } \\
\hline \multicolumn{3}{|c|}{ Organization } & $\begin{array}{c}\text { Up to } 10 \\
\text { years }\end{array}$ & $\begin{array}{c}\text { Above } 10 \\
\text { years }\end{array}$ & \\
\hline \multirow{4}{*}{$\begin{array}{c}\text { *Private } \\
\mathrm{N}=50\end{array}$} & \multirow{3}{*}{$\begin{array}{c}\text { Total } \\
\text { Cholesterol }\end{array}$} & Desirable & $19(38.0)$ & $10(20.0)$ & $29(58.0)$ \\
\hline & & $\begin{array}{l}\text { Boarder } \\
\text { line High }\end{array}$ & $9(18.0)$ & $7(14.0)$ & $16(32.0)$ \\
\hline & & High & $4(8.0)$ & $1(2.0)$ & $5(10.0)$ \\
\hline & \multicolumn{2}{|c|}{ Total } & $32(64.0)$ & 18(360.) & $50(100.0)$ \\
\hline \multirow{4}{*}{$\begin{array}{c}* * \text { Govt. } \\
\mathrm{N}=50\end{array}$} & \multirow{3}{*}{$\begin{array}{c}\text { Total } \\
\text { Cholesterol }\end{array}$} & Desirable & $19(38.0)$ & $10(20.0)$ & $29(58.0)$ \\
\hline & & $\begin{array}{l}\text { Boarder } \\
\text { line High }\end{array}$ & $10(20.0)$ & $6(12.0)$ & $16(32.0)$ \\
\hline & & High & $2(4.0)$ & $3(6.0)$ & $5(10.0)$ \\
\hline & \multicolumn{2}{|c|}{ Total } & $31(62.0)$ & $19(38.0)$ & $50(100.0)$ \\
\hline
\end{tabular}

Table III indicates that of the 42 percent respondents, who had higher than normal cholesterol levels, $62 \%$ of them had an experience of below 10 years. In the case of government hospitals also, of the 42 percent of respondents who had hyper cholesterol levels, majority $(57 \%)$ of them had an experience below 10 years. Probably initial period of employment is associated with more stress, affecting body metabolism. Statistical association were not found to be significant for cholesterol levels and occupational experience $(*$ Chi square $1.002 \mathrm{p}$-value=.606; **Chi square $=1.181 \mathrm{p}$-value=.554).

\section{Association of Cholesterol and Area of Residence}

TABLE IV ASSOCIATION OF TOTAL CHOLESTEROL With RESPECT TO THE AREA OF RESIDENCE

\begin{tabular}{|c|c|c|c|c|c|}
\hline \multirow{2}{*}{\multicolumn{3}{|c|}{ Organization }} & \multicolumn{2}{|c|}{ Area R/U } & \multirow{3}{*}{$\begin{array}{c}\text { Total } \\
29(58.0)\end{array}$} \\
\hline & & & \multirow{2}{*}{\begin{tabular}{|c|} 
Rural \\
$10(20.0)$
\end{tabular}} & \multirow{2}{*}{$\begin{array}{c}\text { Urban } \\
19(38.0)\end{array}$} & \\
\hline \multirow{4}{*}{$\begin{array}{c}* \text { Private } \\
\mathrm{N}=50\end{array}$} & \multirow{3}{*}{$\begin{array}{c}\text { Total } \\
\text { Cholesterol }\end{array}$} & Desirable & & & \\
\hline & & $\begin{array}{c}\text { Boarder } \\
\text { line High }\end{array}$ & $10(20.0)$ & $6(12.0)$ & $16(32.0)$ \\
\hline & & High & $5(10.0)$ & $0(0.0)$ & $5(10.0)$ \\
\hline & \multicolumn{2}{|c|}{ Total } & $25(50.0)$ & $25(50.0)$ & $50(100.0)$ \\
\hline \multirow{4}{*}{$\begin{array}{l}* \text { Govt. } \\
\mathrm{N}=50\end{array}$} & \multirow{3}{*}{$\begin{array}{c}\text { Total } \\
\text { Cholesterol }\end{array}$} & Desirable & $17(34.0)$ & $12(24.0)$ & $29(58.0)$ \\
\hline & & $\begin{array}{c}\text { Boarder } \\
\text { line High }\end{array}$ & $6(12.0)$ & $10(20.0)$ & $16(32.0)$ \\
\hline & & High & $2(4.0)$ & $3(6.0)$ & $5(10.0)$ \\
\hline & \multicolumn{2}{|c|}{ Total } & $25(50.0)$ & $25(50.0)$ & $50(100.0)$ \\
\hline
\end{tabular}


Table IV reveals that of the respondents with high levels of cholesterol in private hospitals $71.4 \%$ belonged to rural area. In the government hospitals $62 \%$ of high and moderate cholesterol patients were from urban areas. Here again the association of area of residence and cholesterol levels were not found to be statistically significant $(*$ Chi square $=8.793$ $\mathrm{p}$-value $=.012 ; * *$ Chi square $=2.062 \mathrm{p}$-value $=.357)$. The lack of association could be due to the small sample size or due to the multiple factors influencing cholesterol levels.

According to our study, this was the first attempt carried out to study the cholesterol levels and prevalence of hypercholesterolemia of nurses working in government and private hospitals of Thiruvananthapuram with respect to their socio economic parameters.

Result of analysis of private hospitals did not reveal significant difference. Respondents of border level and high cholesterol level groups did not vary much in frequency. Analysis of government hospitals showed contradictory trends; respondents of rural areas were higher in border line $(62.5 \%)$ group but lower in hypercholesterolemia group $(40 \%)$. These results are consistent with previous studies showing that alternating shift work adversely affect lipid metabolism (Dochi et al., 2009; Salehi-Marzijarani, 2013).

\section{CONCLUSION}

The prevalence of border line hypercholesterolemia was thirty two percent and the prevalence of high risk hypercholesterolemia was ten percent in nurses of both private and government hospitals. Blood sample analysis reveals that a significant number of respondents were have high risk cholesterol which indicates that irregular shift hours is associated with the risk of hypercholesterolemia. There is scope of analysing into this association through in depth studies.

\section{REFERENCES}

[1] Chen, S., \& Chin-Hsiao, T. (2013). Dyslipidemia, Kidney Disease, and Cardiovascular Disease in Diabetic Patients", The review of diabetic studies, Journal of the society for the biomedical diabetes research, 10(2-3): 88-100. https:// doi: [10.1900/RDS.2013.10.88]

[2] Dochi, M., Suwazono, Y., Sakata, K., Okubo, Y., Oishi, M., Tanaka, K., Kobayash, E., \& Nogawa, K. (2009). Shift work is a risk factor for increased total cholesterol level: a 14-year prospective cohort study in 6886 male workers. Occup Environ Med, 66(9), 592-7. Retrieved from https:// doi: 10.1136/oem.2008.042176.

[3] Menon, A.S., Kotwal. N., Singh, Y., Ashpal, \& Girish, R. (2015), Statins: Cholesterol guidelines and Indian perspective. Indian $J$ Endocrinol Metab., 19(5), 546-553. http:// DOI: 10.4103/22308210.163105

[4] Salehi-Marzijarani, M., Yadegarfar, G., Kazemi, I., Sanati, J., \& Hassanzadeh, A. (2013). Influence of baseline weight on relationship between shift work and longitudinal changes of cholesterol. International JOURNAL of Environmental Health Engineering, 2, 32. http:// DOI: 10.4103/2277-9183.122406 [5] National cholesterol education programme (NCEP), (2013).
Retrieved https://www.wikidoc.org/index.php/Hypercholesterolemia_NCEP_A TP_III_guidelines

[6] Uetani, M., Sakata, K., Oishi, M., Tanaka, K., Nakada, S., Nogawa, K., \& Suwazono, Y. (2011). The influence of being overweight on the relationship between shift work and increased total cholesterol level. Ann Epidemiol 2011 May; 21(5):327-35. https:// doi: 10.1016/j.annepidem.2011.01.001.

[7] Velhal, G.D., Sawant, S., Mahajan, H., \& Rao, A. (2013).Work Related Perceptions among Nursing Staff in Tertiary Care Hospital Of Mumbai, India. IOSR Journal of Nursing and Health Science (IOSR-JNHS), 1(3), 48-55.

[8] WHO (2015). Retrieved from http://www.who.int/news-room/factsheets/detail/cardiovascular-diseases-(cvds). 